\title{
The Skin Microbiota and Itch: Is There a Link?
}

\author{
Hei Sung Kim ${ }^{1,2,3}$ and Gil Yosipovitch ${ }^{1, *}$ \\ 1 Department of Dermatology and Cutaneous Surgery, Miami Itch Center, Miller School of Medicine, \\ University of Miami, Miami, FL 33136, USA; hazelkimhoho@gmail.com \\ 2 Department of Dermatology, Incheon St. Mary's Hospital, The Catholic University of Korea, \\ Seoul 06591, Korea \\ 3 Department of Biomedicine \& Health Sciences, The Catholic University of Korea, 222 Banpo-daero, \\ Seocho-gu, Seoul 06591, Korea \\ * Correspondence: gyosipovitch@med.miami.edu
}

Received: 7 April 2020; Accepted: 20 April 2020; Published: 22 April 2020

\begin{abstract}
Itch is an unpleasant sensation that emanates primarily from the skin. The chemical mediators that drive neuronal activity originate from a complex interaction between keratinocytes, inflammatory cells, nerve endings and the skin microbiota, relaying itch signals to the brain. Stress also exacerbates itch via the skin-brain axis. Recently, the microbiota has surfaced as a major player to regulate this axis, notably during stress settings aroused by actual or perceived homeostatic challenge. The routes of communication between the microbiota and brain are slowly being unraveled and involve neurochemicals (i.e., acetylcholine, histamine, catecholamines, corticotropin) that originate from the microbiota itself. By focusing on itch biology and by referring to the more established field of pain research, this review examines the possible means by which the skin microbiota contributes to itch.
\end{abstract}

Keywords: itch; skin microbiota; stress; microbiota-skin-brain axis

\section{Introduction}

Bacteria, viruses, fungi, archaea, helminths, and protozoa that inhabit our body are a prospering dynamic community shaping a symbiotic superorganism. Roughly $10^{14}$ microbiota populate the entire body, with their number approximating that of human cells [1,2]. Evidence suggests that microbiota take part in maintaining human health [3,4].

As a crucial barrier to the exterior world, skin is one of the body's largest organ [5]. A square centimeter of human skin holds around $10^{6}$ of microbiota [6-8]. The symbionts defend against illness by regulating the skin barrier and host immune response $[9,10]$. On the other hand, microbial imbalance (dysbiosis) has been noted to exacerbate skin lesions and delay wound healing [11,12]. Recently, the emerging role of the skin microbiota in itch has received attention [13].

Large-scale changes of the skin microbiota have been noted in itchy skin diseases. Staphylococcus aureus (S. aureus) participates in atopic dermatitis (AD) flare-up; its colonization correlates with disease severity and itch [14-16].

In the present review, we offer an integrative perspective on the skin microbiota and itch. The first section describes the interplay of the cutaneous microbiota with the epidermal barrier, the local immune system, and the sensory nerve, proposing the microbiota's peripheral mechanism of itch. The second section concentrates on the concept of microbial endocrinology and addresses the microbiota-skin-brain axis. Moreover, the interaction between the skin microbiota and the amygdala is discussed to explain the microbiota's central mechanism of itch. Overall, this article describes the putative role of the skin microbiota in itch. 


\section{The Peripheral Mechanism Linking the Skin Microbiota and Itch}

Itch arises from the activation of epidermal nerve fibers that belong to a specialized class of itch-provoking neurons ("pruriceptors"). The chemical mediators that drive neuronal activity arise from complex interaction between keratinocytes, inflammatory cells, and nerve endings, coupled with upregulated immune cascades, epidermal barrier dysfunction and exogenous environmental stimuli (i.e., microbiota, allergens, irritants) [17]. Peripheral nerves relay cues from the skin to the dorsal root and trigeminal ganglia and then to the spinal cord and brain where central itch processing takes place (Figure 1) [17].

\subsection{The Skin Microbiota, The Skin Barrier, and Itch}

The skin barrier shields the body from a wide range of external dangers [18]. It consists of the epidermis and several layers below that harbor microbiota [19-21]. The physical skin barrier is the stratum corneum, which comprises dead keratinocytes (KCs) and proteinaceous crosslinking filaments [22].

The skin also has a chemical barrier of antimicrobial peptides (AMPs) that are constitutively expressed or induced. AMPs directly block microbial growth or provoke the immune reaction. One example is the liberation of histamine and prostaglandin $\mathrm{D}_{2}\left(\mathrm{PGD}_{2}\right)$ [23] by mast cells in respect to human $\beta$-defensins (hBDs) and LL-37, which causes pruritus.

The skin microbiota is an integral part of the skin barrier [18]. It protects the host from pathogens by competing for nutrients and space [19]. Some produce antimicrobial compounds, which block the growth of competitors [19]. Symbionts also alter the skin barrier via bacterial enzymes, such as proteases that impact corneocyte desquamation, or lipases, which break down skin surface lipids [24].

Staphylococcus epidermidis (S. epidermidis) is the primary bacterium colonizing the human epithelia and is a vital member of the skin resident microbiota [25]. S. epidermidis has a flexible interrelation with its host, and deposits biofilms (a physical barrier) that are remarkably hard to clear [26]. Symbiont strains of S. epidermidis suppress S. aureus biofilm formation by producing serine protease (Esp), which also enhances the antimicrobial effect of hBD2 [27]. Another typical skin resident is Cutibacterium acnes (C. acnes) which inhibits the growth of methicillin-resistant S. aureus (MRSA) [28]. In short, C. acnes ferments glycerol, a natural metabolite in human skin, into short-chain fatty acids (SCFAs) that maintain an acidic skin $\mathrm{pH}$ [29]. Symbionts flourish at acidic $\mathrm{pH}$, whereas potential pathogens, such as S. aureus, thrive at neutral $\mathrm{pH}[30,31]$.

Intrinsic (host) and extrinsic (environmental) factors affect skin barrier function by shaping microbial structure [32]. S. aureus colonization is found in up to $90 \%$ AD patients [33]. It produces ceramidase, which breaks down ceramides, an essential component of the skin barrier [34]. S. aureus also produces $\alpha$ toxins that impede wound healing and bring epithelial barrier disintegration [35].

Scabies mites (Sarcoptes scabiei) alter the skin microbiota by breaching the physical barrier. Epidemiologic studies in scabies patients confirmed secondary bacterial infections by two clinically important pathogens S. aureus and Streptococcus pyogenes [36].

Lately, there has been a growing awareness of fungi and their interaction with the skin barrier. When the chemical composition (i.e., sweat, $\mathrm{pH}$ ) of the host epidermis is disturbed, Malassezia spp. acquire pathogenicity and liberate an array of bioactive indoles, lipases, and phospholipases [37]. These molecules further modify the function of the skin barrier.

Epithelial barrier disruption is a door opener into a vicious itch-scratch cycle [38,39]. Upon damage or stress, keratinocytes (KCs) and skin microbiota emit cytokines, AMPs, and proteases that activate immunocytes and nerves [38,40,41]. Protease-activated receptors (PARs), which are cleaved by serine proteases, manifest on different cell types, including sensory neurons and mediate itch [42-45]. $\beta$-defensin, an AMP released from epithelial cells, has the ability to stimulate IL-31 production by mast cells [46]. IL-31, initially discovered in 2004, is the first cytokine that is known to facilitate itch by directly operating on sensory neurons [47]. 


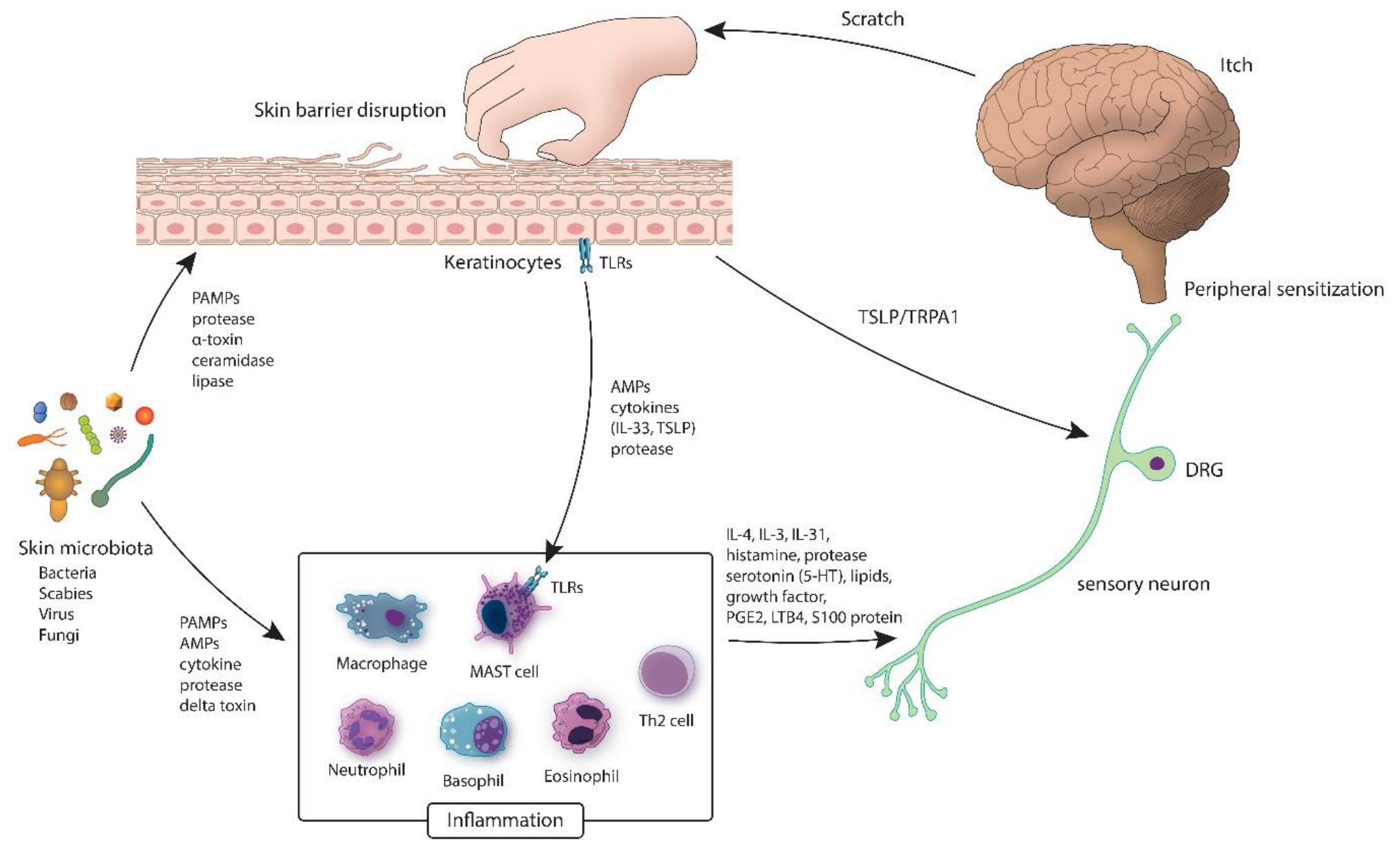

Figure 1. Inflammatory circuit of the skin microbiota. Various microbiota (bacteria, fungi and viruses) cover the exterior of a healthy skin where the barrier is intact. In the event of dysbiosis, pathogens release proteases, which may disrupt the epidermal barrier. Delta-toxin causes mast cell degranulation, which prompt inflammation and itching. AMP: antimicrobial peptides; DRG: dorsal root ganglia; IL: interleukin; LTB4: leukotriene B4; PAMP: pathogen associated molecular pattern; PGE2: prostaglandin E2; TLR: Toll-like receptor; TRPA1: transient receptor potential antigen 1; TSLP: thymic stromal lymphopoietin. 


\subsection{The Skin Microbiota, The Immune System, and Itch}

Skin is flushed with a wide scope of cells of the innate and adaptive immune system. The skin microbiota keeps immune homeostasis [19] by modulating the expression of diverse innate factors, including AMPs, interleukin 1a (IL-1a) [48], and complement [49].

Symbionts calibrate inflammation $[50,51]$. S. epidermidis suppresses inflammation by inducing IL-10, an anti-inflammatory cytokine, from antigen-presenting cells (APCs) [52]. The Toll-like-receptor (TLR)-2-facilitated recognition of lipoteichoic acid (LTA) from S. epidermidis inhibits TLR-3-driven inflammatory cytokine production in cultured keratinocytes (Table 1). This also reduces inflammation in wounds, a condition where uncontrolled inflammation is damaging to the host [52].

Table 1. Interaction between the skin microbiota and the Toll-like receptors (TLRs).

\begin{tabular}{|c|c|}
\hline Bacteria & Interactions with TLRs \\
\hline S. epidermidis & $\begin{array}{l}\text { Adjusts TLR3-dependent inflammation by introducing a TLR2-mediated crosstalk to } \\
\text { subdue inflammation [52]. } \\
\text { Elicits keratinocytes to display AMPs through a TLR2-dependent mechanism [50]. }\end{array}$ \\
\hline S. aureus & $\begin{array}{l}\text { Induction of hBD3 gene expression is TLR2-dependent [53]. } \\
\text { Lipoteichoic acid and bacterial lipoproteins act as TLR2/2 or TLR2/6 agonists [54,55]. }\end{array}$ \\
\hline P. acnes & $\begin{array}{l}\text { Colonizes sebaceous glands and stimulates KCs to release inflammatory cytokines via } \\
\text { TLR2 activation [56]. }\end{array}$ \\
\hline
\end{tabular}

Finally, S. epidermidis can finely tune the response of resident $\mathrm{T}$ cells and promote selective immunity against skin pathogens [57].

Alteration in the normal makeup of the skin microbiota induces inflammation. Moreover, the constitution of the cutaneous microbiota shifts dramatically in the course of inflammation [14]. For example, AD flares are tied with an overall decrease in microbial diversity with an expansion of staphylococcal species [14]. The resulting bacterial and viral infection can cause itch.

One possible mechanism of itch from $S$. aureus infection is mast cell-mediated pruriceptor stimulation. Nunez et al. discovered that $S$. aureus releases delta-toxin, an amphipathic peptide that stimulates chemical release from mast cells and mediates skin pathology in AD [58]. Serine protease from S. aureus is also involved in type-2 inflammation and itch [16,59].

Varicella zoster virus (VZV) causes pruritus in chickenpox by mast-cell-derived histamine [60].

KCs first detect pathogens and initiate an immune response [61]. KCs identify an array of microbial ligands via Toll-like receptors (TLRs) exhibited on their surface [62-64]. In response to stimulation, KCs produce alarmins or epithelial cell-derived cytokines (i.e., IL-33, thymic stromal lymphopoietin (TSLP)) [65] which potentiate innate and adaptive immunity [61]. TSLP also acts upon a subdivision of TRPA1 sensory neurons to spark itch [65].

Mast cells (MCs) are also an essential element of innate immunity. MCs recognize pathogens via pathogen-associated molecular pattern (PAMP) receptors (i.e., TLR) on their surface [66]. Once they detect pathogens, inflammatory mediators are released to attract other immune cells $[67,68]$.

Downstream of IL-33 and TSLP, mast cells, neutrophils, basophils, eosinophils, Th2 cells, and macrophages generate cytokines (IL-4, IL-13, IL-31), histamine, proteases, serotonin (5-HT), lipids, S100 proteins, prostaglandin E2 (PGE2), leukotriene B4 (LTB4), and growth factors [69-71]. Recognizing these pro-inflammatory molecules via TRPV1 and TRPA1 channels leads to action potential propagation across the afferent itch pathway [72].

Th2 immunity is dominant in scabies and is complemented by a heavy inflow of IL-31(+) M2 macrophages [73]. Proteases from scabies mite stir epidermal KCs to express TSLP. TSLP activates Th2 cells and induces M2 macrophages to produce IL-31, causing severe itch [74]. The antigens of S. aureus have also been reported to induce IL-31 in individuals with AD [75]. 


\subsection{The Skin Microbiota, The Sensory Nerve, and Itch}

Skin is one of the first lines of defense against microbial threats. Though the immune system is an essential component of cutaneous immunity, it is evident that the sensory nervous system also plays an important part in host defense. By evoking the sensation of itch, the host can immediately sense danger and rapidly initiate a protective behavioral response [69].

A network of high- and low-threshold sensory nerves innervates the skin and is frequently exposed to bacterial pathogens (Figure 2).

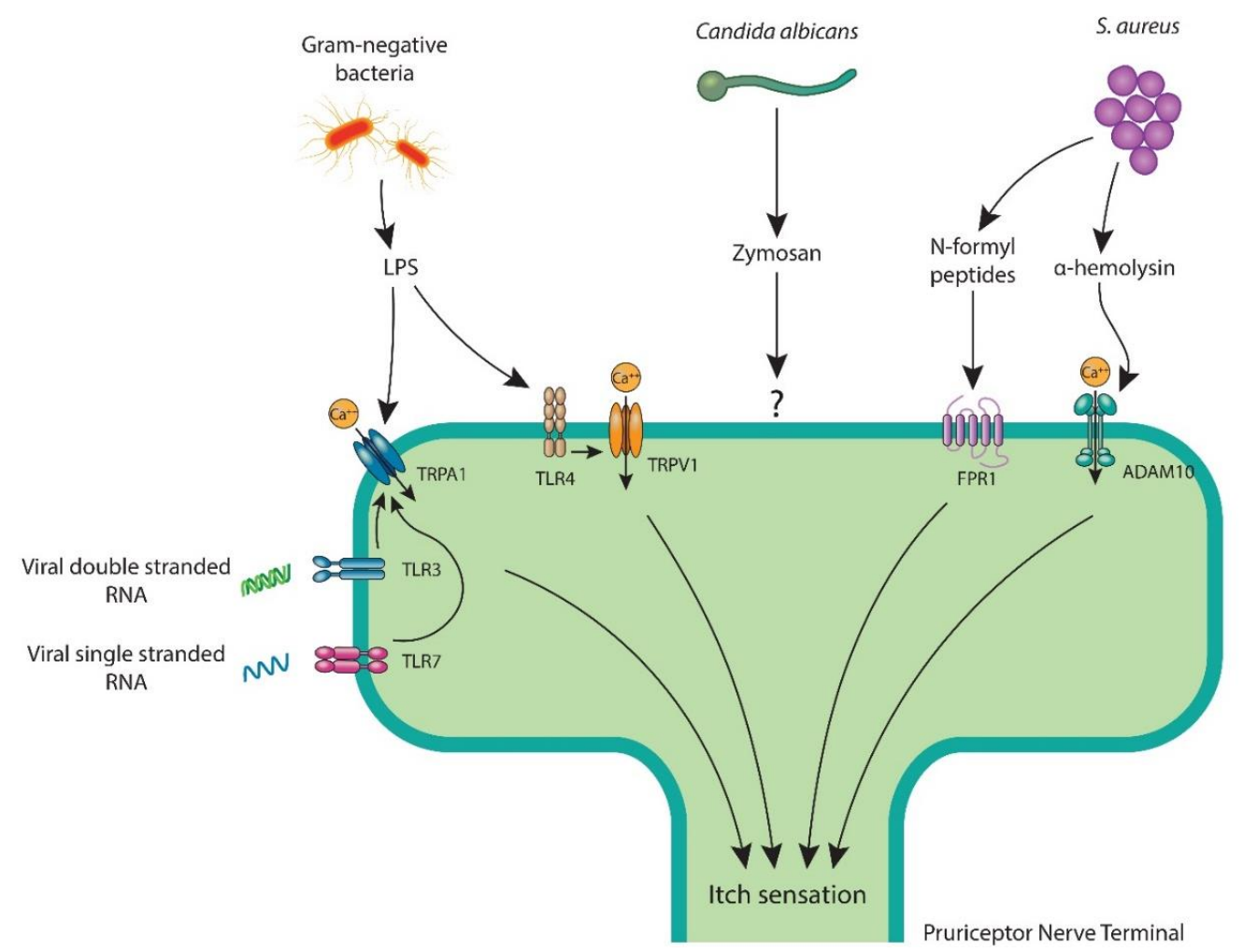

Figure 2. Pruriceptor neurons recognize skin pathogens and their molecular ligands by various mechanisms to facilitate itch. LPS, a key cell wall component of Gram-negative bacteria attaches to neuronal TLR4 and primes TRPV1 ion channel or opens the TRPA1 ion channel. S. aureus triggers itch with bacterial $\mathrm{N}$-formyl peptides that bind to FPR1 or via $\alpha$-hemolysin, which couples with ADAM10. C. albicans stimulates pruriceptors with its cell wall component zymosan. Viral double-strand RNA and single-strand RNA bind to TLR3 and TLR7, respectively, which are believed to sensitize the TRPA1 ion channel. ADAM10: a disintegrin and metalloproteinase domain-containing protein 10; FPR1: formyl peptide receptor 1; LPS: lipopolysaccharide; RNA: ribonucleic acid; TLR: Toll-like receptor; TRPA1: transient receptor potential ankyrin 1; TRPV1: transient receptor potential vanilloid 1.

Pruriceptor neurons express cytokine receptors and $G$ protein-coupled receptors that recognize immune mediators [76]. While we understand that microbial inflammation propagates itch, how the skin microbiota directly triggers sensory nerves is a new area of inquiry.

The latest studies suggest that sensory neurons, like immune cells, are able to detect microbiota $[13,69,76,77]$. Ji and colleagues reported TLR7 on pruriceptors and noted synthetic TLR7 ligands (i.e., imiquimod) causing itch behavior in mice [78]. TLR3 is also displayed by pruriceptors, where Polyl:C, a TLR3 ligand, stimulates neuronal activity and itch [79]. Viral single-stranded RNA and double-stranded RNA are known pathogen-derived ligands for TLR7 and TLR3, respectively, and there is a possibility that these viral ligands cause itch by directly interacting with pruriceptor neurons [76]. 
Lipopolysaccharide (LPS), an important component of the Gram-negative bacteria outer membrane, binds to TLR4 [80]. Although LPS has only been reported with pain [81], it can also modulate itch since TLR4 promotes histamine-mediated itch [82]. Interestingly, LPS has also been found to stimulate sensory neurons in an TLR4-independent manner, via the activation of TRPA1 [83,84].

Besides TLR ligands, sensory neurons notice pathogens through various molecular means. Specifically, zymosan from Candida albicans [85], N-formylated peptides and $\alpha$-hemolysin from S. aureus [86], and streptolysin S from S. pyogens [87] were shown to mediate pain through direct neuronal stimulation. It remains to be discovered whether pruriceptors recognize these pathogens in a matching manner to elicit itch.

Itch is bothersome in patients with cholestatic liver disease [88]. Recently, alteration of the skin microbiota was identified in cirrhosis patients where specified microbial taxa correlated with itch severity and serum autotaxin (ATX) level [89]. Lysophosphatidic acid (LPA), a powerful neuronal activator, and ATX (ectonucleotide pyrophosphatease/ phosphodiesterase 2), the enzyme that creates LPA, are pruritogens in cholestasis $[90,91]$. It is suggested that LPA directly activates TRPV1 on peripheral sensory neurons to mediate itch [92].

Neuroimmune conversation is bidirectional in itch. Sensory neurons are sensitized by immune cell-made cytokines (i.e., TNF- $\alpha$, IL-1 $\beta$ ), chemicals (i.e., histamine), and lipid mediators (i.e., prostaglandins), which phosphorylate ion channels and lower the bar of action potential firing. Neurons, in turn, secrete neuropeptides (i.e., calcitonin gene-related peptide, substance P) that modulate immune cell function [93,94] and microbial virulence [95-97] causing itch [98]. As neurons respond within milliseconds of facing danger, the sensory nervous system is likely the first to notice pathogen invasion and the prime orchestrator itch [76].

\section{The Central Mechanism Linking the Skin Microbiota and Itch}

\subsection{Microbial Endocrinology}

Microbial endocrinology is a crossing of two supposedly distinct areas, microbiology and neurobiology, and is based on the shared presence of neurochemicals in the host and the microbiota [66].

The scope of neurochemicals and the variety of microbiota in which they are discovered is huge [99]. These include acetylcholine [100,101], histamine [102,103], serotonin [104], catecholamines [105,106], and agmatine $[107,108]$, which are essential elements of an animal's nervous system. Others, such as corticotropin [109], somatostatin [110], and progesterone [111], have biological action in mammalian cells.

The ability of the microbiota to not only respond to but also create the very same neurochemicals of mammalian systems, tells that host interplay with the microbiota is much more interactive than it was thought before.

Hence, microbial endocrinology could be applied beyond infectious disease to other conditions such as brain health through the microbiota-skin-brain axis.

Microbiota has multiple transmission pathways to access the brain: the neural signals carried by the afferent neurons, endocrine messages transmitted by neurochemicals and the immune messages transferred by cytokines [112,113].

The skin is one important platform for microbial communication with the brain. In an evolutionary standpoint, it is reasonable for the skin to support the cutaneous microbiota, which in turn assists skin barrier function and local immune system and helps the skin communicate with other organ systems, including the brain (microbiota-skin-brain axis) [114].

\subsection{Stress, The Skin Microbiota, and Itch}

Stress is a complex dynamic condition where homeostasis, or the stability of an organism is altered, promoting the adaptation of the host. Stress aggravates itch [115-117], which proves that the brain is engaged in the final common stage of itch processing $[118,119]$. 
Stress acts by the central nervous system (CNS) and alters the microbiota via the release of neurochemicals [120,121]. Glucocorticoids, an essential component of the stress response, repress AMP release/localization in the epidermis, weaken the barrier, and raise host susceptibility to infection [122-124].

Chronic stress is associated with an aberrant parasympathetic tone (Figure 3) $[125,126]$. Cholinergic signaling from physiologic stress [125] negatively impacts the skin barrier and immunity $[127,128]$. Cathelicidin and $\beta$-defensins, AMPs important for innate immunity, were cut down after $\alpha 7 \mathrm{nAChR}$ stimulation [128,129], leading to bacterial dissemination.

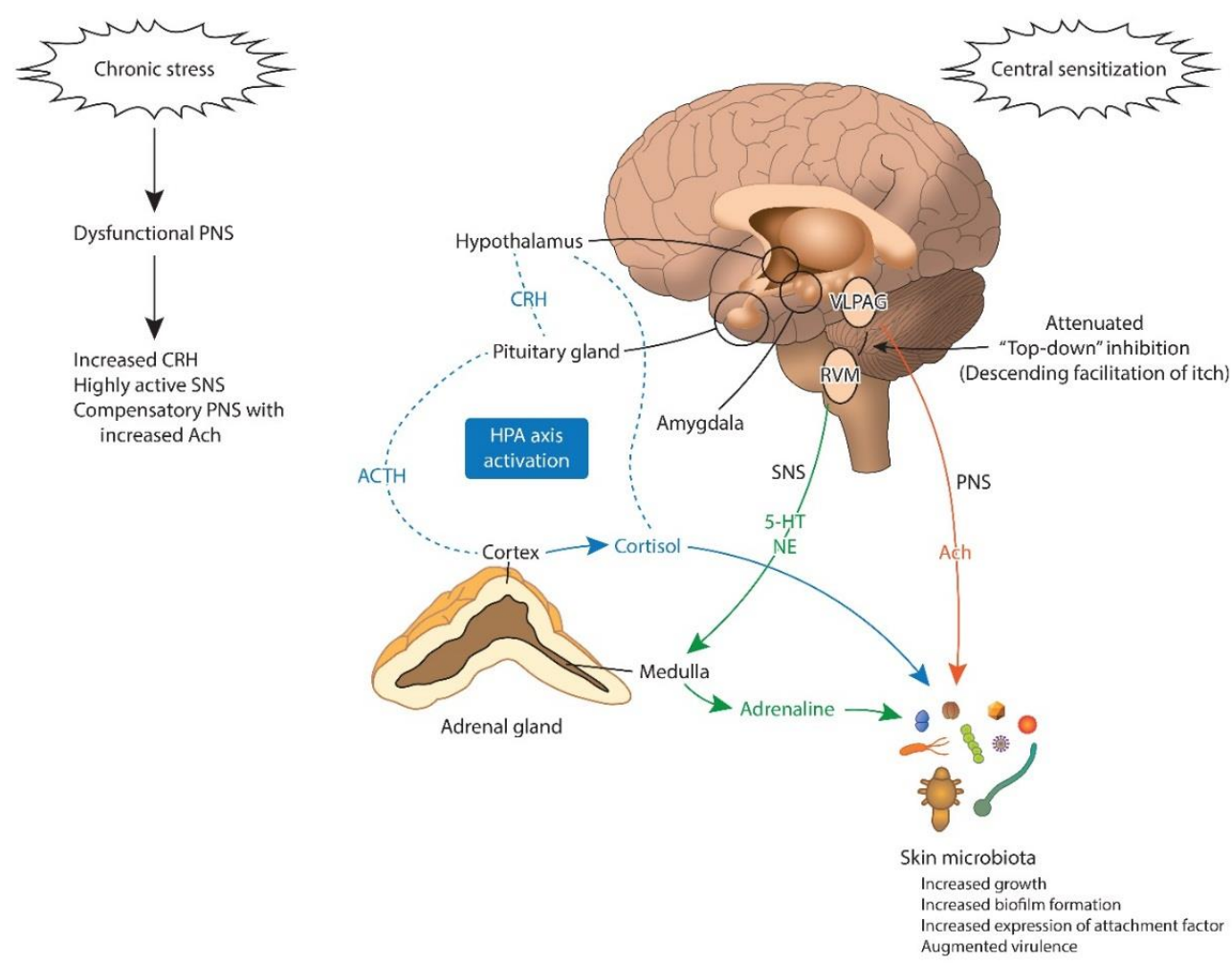

Figure 3. Brain to microbiota communication under chronic stress. The HPA axis is activated under chronic stress. The final product of the HPA axis, cortisol, directly activates skin microbes. Cortisol activates the amygdala, promoting central sensitization to itch. The amygdala also promotes $\mathrm{CRH}$ signaling to the brain stem (PAG), altering the "descending itch modulatory system". Prolonged exposure to cortisol, NE, and ACTH is associated with increased growth and biofilm genesis and augmented virulence of the skin microbiota. Ach: acetylcholine; ACTH: adrenocorticotropic hormone; CRH: corticotropin-releasing-hormone; HPA: hypothalamic-pituitary-adrenal axis; 5-HT: serotonin; NE: norepinephrine; PNS: parasympathetic nervous system; RVM: rostral ventromedial medulla; SNS: sympathetic nervous system; VLPAG: ventrolateral periaqueductal grey matter

Skin microbiota, especially the coagulase-negative staphylococci, are sensitive to catecholamines. Norepinephrine (NE), epinephrine, dopamine, and their structurally related inotropes (dobutamine and isoprenaline) raise staphylococcal growth by 5-log orders or more [130-132]. Catecholamines also strengthen bacterial attachment to host tissues and increase bacteria virulence $[130,133,134]$. Catecholamines stimulate the biofilm formation of Pseudomonas aeruginosa (P. aeruginosa) and Escherichia coli (E. coli) [124,135]. Within a polymirobial biofilm, P. aeruginosa enhances USA300 methicillin-resistant $S$. aureus virulence [136].

Substance $P$ is released in sweat during stress and increases the virulence of Gram-positive skin bacteria, namely S. aureus and S. epidermidis $[95,96]$. 
Thus, the effect of stress on the skin microbiota may be twofold: dampening the host defense to infection and adjusting the microenvironment ideal for pathogens [124]. The resultant dysbiosis can exacerbate itch ("stress aggravated itch") (Table 2).

Table 2. Effects of stress mediators on the skin microbiota.

\begin{tabular}{ll}
\hline Bacteria & Effects of Stress Mediators \\
\hline Staphylococcus epidermidis & $\begin{array}{l}\text { Glucocorticoids decrease the effects of super antigen activated T cells and inhibit staphylococcal } \\
\text { exotoxin-induced T cell proliferation, cytokine secretion [137]. } \\
\text { Catecholamines induce biofilm growth [130]. }\end{array}$ \\
\hline Propionibacterium acnes & $\begin{array}{l}\text { Cortisol and steroids significantly exacerbate inflammation associated with P. acnes via TLR2 } \\
\text { stimulation [138,139]. }\end{array}$ \\
\hline Pseudomonas aeruginosa & $\begin{array}{l}\text { Norepinephrine increases expression of the attachment factor PA-1 of P. aeruginosa and increase } \\
\text { biofilm formation [135,138]. }\end{array}$ \\
\hline Staphylococcus aureus & $\begin{array}{l}\text { Acetylcholine augments susceptibility to infection by S. aureus [124]. } \\
\text { Norepinephrine increases S. aureus' ability to remove iron from host and therefore facilitates the } \\
\text { bacteria to form biofilms [138,140]. }\end{array}$ \\
\hline Group A Streptococcus & $\begin{array}{l}\text { Cortisol alters vulnerability to Group A Streptococcus pyogenes skin infection [141]. } \\
\text { Acetylcholine augments susceptibility to infection by Group A Streptococcus [124]. } \\
\text { Catecholamines raise Staphylococcal growth by 5-log orders [130-132]. } \\
\text { Catecholamines enhance Group A Streptococcus growth likely by increasing iron availability [138,142]. }\end{array}$ \\
\hline Candida & Estrogen enhances Candida infectivity, switching yeast form to an invasive hyphae [143]. \\
\hline
\end{tabular}

\subsection{The Skin Microbiota, The Amygdala, and Itch}

Itch encompasses sensory-discriminative and affective-motivational aspects and undergoes extensive processing in the higher brain centers [119,125].

The Amygdala is involved in pain, especially in the emotional-affective aspects of pain perception [144]. The central nucleus of the amygdala (CeA) is commonly called the "nociceptive amygdala" [145] and receives peripheral pain signals via the parabrachial nucleus [146].

The role of amygdala in itch is also shown in animal studies [147]. A recent study noted that scratching was suppressed after blocking itch-mediating spinal neurons connected to the spinoparabrachial pathway [148]. Additionally, an animal functional MRI (fMRI) study presented amygdala activation during itch stimuli [149]. The findings hint that itch signals are delivered by both the spinothalamic pathway and the spinoparabrachial-CeA path. It was claimed that the injection of muscimol ( $\gamma$-aminobutyric acid agonist) to the amygdala minimized scratching elicited by the injection of serotonin to the cheek, implying a modulatory role of the amygdala in itch processing [150].

Chronic stress brings functional and configurational changes in the amygdala (central sensitization) (Figure 3) [151]. This change may influence itch processing in the brain, which explains why stress worsens itch in individuals with chronic itch [152,153].

Studies suggest that the amygdala itself is susceptible to microbial influences [154]. Most convincingly, data from germ-free (GF) mice imply that the amygdala transcriptome becomes hyperactive in the absence of microbiota $[155,156]$. This hyperactive state is in line with the altered pain sensitivity [157] and stress response in GF mice [158,159].

We do not know how microbial signals navigate through the skin-brain axis to reach the amygdala specifically yet; however, there are some strong candidate paths, including the blood stream (circulation) and the spinal cord $[112,154,160]$.

\section{Conclusions and Future Perspectives}

With increased recognition of the presence and functionality of the microbiota, the human body is not what we perceive. Evidence suggests that our microbiota occupies a prominent role in the human body than formerly thought.

Cutaneous microbiota delivers a diverse and far-reaching influence on our physiology by calling upon the host nervous system. Bacteria make metabolites, toxins, and structural components that 
are recognized by peripheral and central neurons via matching receptors. Microbiota also indirectly affects neural function by causing endocrine (i.e., keratinocytes) and immune cells to transmit signals (i.e., cytokines, proteases). Itch is a prototypic sensory neural function, and the microbiota propels the itch-scratch cycle.

Some descriptive studies have differentiated the microbiota found in itchy skin versus those of healthy skin. While dysbiosis is found in various pathologies, these raise a "chicken-or-the-egg" type question, as we are not sure if dysbiosis leads to disease, or whether the underlying conditions cause microbial imbalance.

To differentiate cause and effect, a deeper and more mechanistic (functional) understanding of the skin microbiota's role in itch is required. Increased grasp of this area will help find microbiological markers in itchy conditions and develop alternative therapeutics which utilize host-microbiota relationship.

The gut and skin are uniquely related in function, and numerous studies link gut microbiota to skin homeostasis (skin-gut axis or skin-gut-brain axis) [35,161-164]. Commonalities have also been found between itch transition in the skin and neural signaling in the lower intestinal tract, which raises the possibility of intestinal microbiota playing a role in itching $[165,166]$.

Various types of microbiota-based therapy may be applied in the upcoming years: (1) Whole microbiota transplant, a process that offers microbiota from healthy donors to patients with significant skin dysbiosis, such as AD, to correct the dysbiosis. The favorable effects of microbial transplant can be studied for other itchy conditions as well. (2) Topical probiotics can be used to introduce known advantageous microbiota to a patient (especially at a critical age for immune and limbic brain wiring). (3) Topical prebiotics (nutrients that stimulate beneficial skin micrbiota, or biomass or dead extracts of non-pathogenic bacteria which antagonize substance P) can be adopted. (4) Host-microbiota interplay can be studied by analyzing microbial metabolites, re-imposing commensal microbial activity by offering signaling molecules (Figure 4).

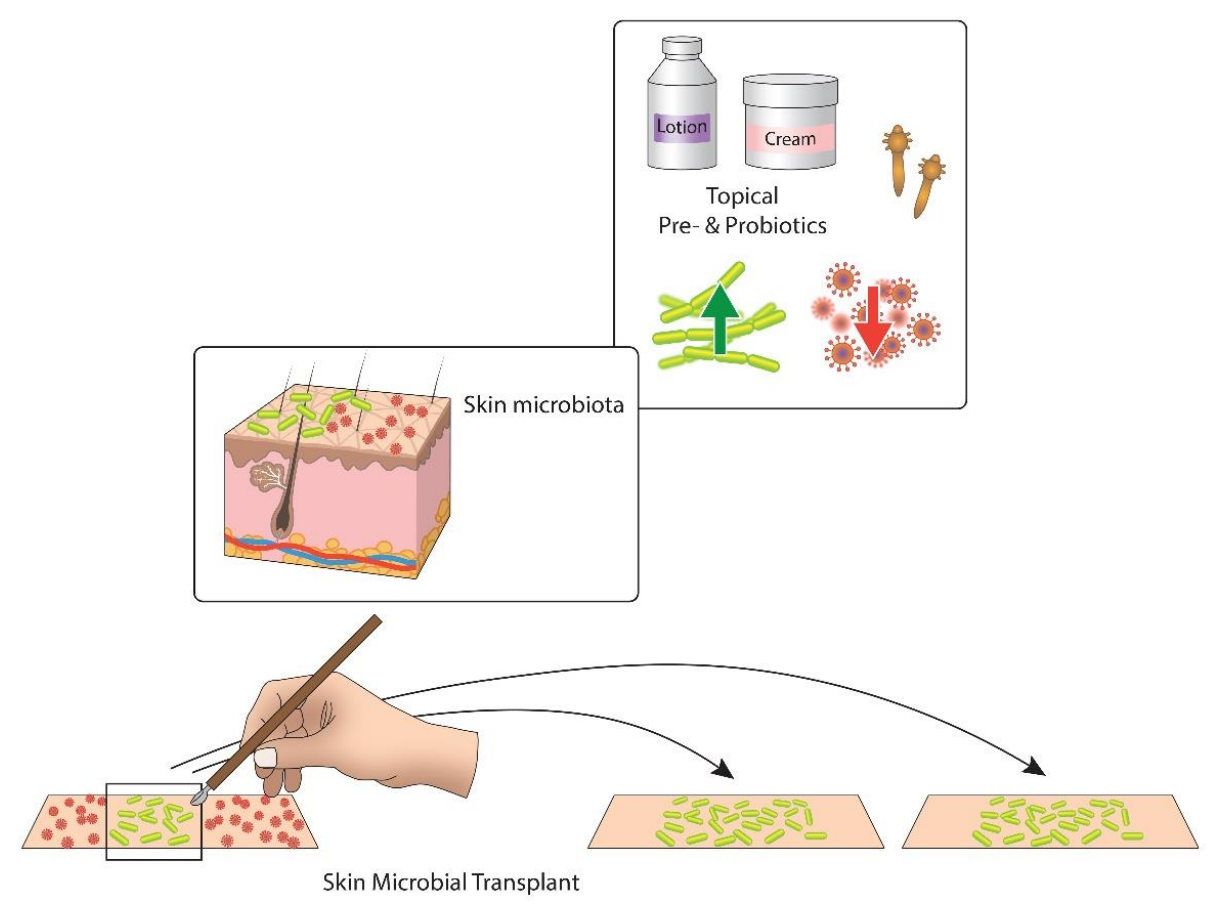

Figure 4. Two main approaches of controlling the human skin microbiota for the itch control. Topical pre- and probiotics target to increase the number of advantageous bacteria (green) and reduce pathogens (red). Skin microbial transplant is a new approach that transfers beneficial microbiota from healthy skin to itchy and dysbiotic skin [167]. 
In conclusion, the interplay between the skin microbiota and itch is an emerging area to explore. In future, cosmetics/transdermal drugs with a concept of 'topical microbiota modulator' could have the potential to claim that they do not only make you look good but also that make you feel good.

Author Contributions: All authors made substantial contributions to the concept and design of the work and approved the submitted version (Conceptualization, H.S.K., and G.Y.; Writing-Original Draft Preparation, Review and Editing, H.S.K., and G.Y.; Funding Acquisition, H.S.K.). All authors have read and agreed to the published version of the manuscript.

Funding: This study was supported by a National Research Foundation of Korea (NRF) grant founded by the South Korean Government (2017R1C1B5016144).

Conflicts of Interest: Yosipovitch reports serving on the scientific board and being a consultant for Trevi, Sanofi Regeneron, Galderma, Pfizer, Novartis, Kiniksa, Eli Lilly, Bellus, LEO and is supported by Sun Pharma, Pfizer, Novartis, Kiniksa, Leo Pierre Fabre. None of these involvements had influence on the content of the presented paper.

\section{Glossary}

\begin{tabular}{ll}
\hline Term & Definition \\
\hline 16S rRNA gene sequencing & $\begin{array}{l}\text { Genomic analysis of 16S ribosomal RNA phylotypes from DNA that is extracted directly from } \\
\text { bacterial communities in clinical or environmental samples, a process that circumvents culturing [29]. }\end{array}$ \\
\hline Skin microbiota & Total of microbes in/on our skin [168]. \\
\hline Microbiota & The group of microbes found in/on a specific environment or living host [169]. \\
\hline Microbial diversity & $\begin{array}{l}\text { Degree of variability of the microbiota. } \alpha \text {-diversity describes within-sample variability, while } \\
\beta \text {-diversity signifies variability between samples [169]. }\end{array}$ \\
\hline Dysbiosis & Microbial imbalance or maladaptation [168]. \\
\hline Prebiotics & Nutrients that stimulate beneficial skin microorganisms [170]. \\
\hline Probiotics & Live microorganisms that have a favorable impact on host health when given in proper amounts [169]. \\
\hline Antibiotics & Antibiotics block the growth of or destroy bacteria and other microbes [168]. \\
\hline
\end{tabular}

\section{References}

1. Sender, R.; Fuchs, S.; Milo, R. Are we really vastly outnumbered? Revisiting the ratio of bacterial to host cells in humans. Cell 2016, 164, 337-340. [CrossRef] [PubMed]

2. Bianconi, E.; Piovesan, A.; Facchin, F.; Beraudi, A.; Casadei, R.; Frabetti, F.; Vitale, L.; Pelleri, M.C.; Tassani, S.; Piva, F; et al. An estimation of the number of cells in the human body. Ann. Hum. Biol. 2013, 40, 463-471. [CrossRef] [PubMed]

3. Yang, N.J.; Chiu, I.M. Bacterial signaling to the nervous system through toxins and metabolites. J. Mol. Biol. 2017, 429, 587-605. [CrossRef] [PubMed]

4. Chen, Y.E.; Fischbach, M.A.; Belkaid, Y. Skin microbiota-host interactions. Nature 2018, 553, 427-436. [CrossRef] [PubMed]

5. Gallo, R.L. Human skin is the largest epithelial surface for interaction with microbes. J. Investig. Dermatol. 2017, 137, 1213-1214. [CrossRef]

6. Fyhrquist, N.; Salava, A.; Auvinen, P.; Lauerma, A. Skin biomes. Curr. Allergy Asthma Rep. 2016, 16, 40. [CrossRef]

7. Sender, R.; Fuchs, S.; Milo, R. Revised estimates for the number of human and bacteria cells in the body. PLoS Biol. 2016, 14, e1002533. [CrossRef]

8. Leyden, J.J.; McGinley, K.J.; Nordstrom, K.M.; Webster, G.F. Skin microflora. J. Investig. Dermatol. 1987, $88,65 \mathrm{~s}-72 \mathrm{~s}$. [CrossRef]

9. Wang, W.M.; Jin, H.Z. Skin microbiome: An actor in the pathogenesis of psoriasis. Chin. Med. J. (Engl.) 2018, 131, 95-98. [CrossRef] [PubMed]

10. Trivedi, B. Microbiome: The surface brigade. Nature 2012, 492, S60-S61. [CrossRef]

11. Gontcharova, V.; Youn, E.; Sun, Y.; Wolcott, R.D.; Dowd, S.E. A comparison of bacterial composition in diabetic ulcers and contralateral intact skin. Open Microbiol. J. 2010, 4, 8-19. [CrossRef] [PubMed] 
12. Johnson, T.R.; Gomez, B.I.; McIntyre, M.K.; Dubick, M.A.; Christy, R.J.; Nicholson, S.E.; Burmeister, D.M. The cutaneous microbiome and wounds: New molecular targets to promote wound healing. Int. J. Mol. Sci. 2018, 19, 2699. [CrossRef] [PubMed]

13. Chiu, I.M. Infection, pain, and itch. Neurosci. Bull. 2018, 34, 109-119. [CrossRef]

14. Kong, H.H.; Oh, J.; Deming, C.; Conlan, S.; Grice, E.A.; Beatson, M.A.; Nomicos, E.; Polley, E.C.; Komarow, H.D.; Murray, P.R.; et al. Temporal shifts in the skin microbiome associated with disease flares and treatment in children with atopic dermatitis. Genome Res. 2012, 22, 850-859. [CrossRef] [PubMed]

15. Blicharz, L.; Usarek, P.; Mlynarczyk, G.; Skowronski, K.; Rudnicka, L.; Samochocki, Z. Is itch intensity in atopic dermatitis associated with skin colonization by Staphylococcus aureus? Indian J. Dermatol. 2020, 65, 17-21. [CrossRef]

16. Allen, H.B.; Vaze, N.D.; Choi, C.; Hailu, T.; Tulbert, B.H.; Cusack, C.A.; Joshi, S.G. The presence and impact of biofilm-producing staphylococci in atopic dermatitis. JAMA Dermatol. 2014, 150, 260-265. [CrossRef]

17. Azimi, E.; Xia, J.; Lerner, E.A. Peripheral mechanisms of itch. Curr. Probl. Dermatol. 2016, 50, 18-23. [CrossRef]

18. Baldwin, H.E.; Bhatia, N.D.; Friedman, A.; Eng, R.M.; Seite, S. The role of cutaneous microbiota harmony in maintaining a functional skin barrier. J. Drugs Dermatol. 2017, 16, 12-18. [CrossRef]

19. Sanford, J.A.; Gallo, R.L. Functions of the skin microbiota in health and disease. Semin. Immunol. 2013, 25, 370-377. [CrossRef]

20. Nakatsuji, T.; Chiang, H.I.; Jiang, S.B.; Nagarajan, H.; Zengler, K.; Gallo, R.L. The microbiome extends to subepidermal compartments of normal skin. Nat. Commun. 2013, 4, 1431. [CrossRef]

21. Proksch, E. pH in nature, humans and skin. J. Dermatol. 2018, 45, 1044-1052. [CrossRef] [PubMed]

22. Boer, M.; Duchnik, E.; Maleszka, R.; Marchlewicz, M. Structural and biophysical characteristics of human skin in maintaining proper epidermal barrier function. Postepy Dermatol. Alergol. 2016, 33, 1-5. [CrossRef] [PubMed]

23. Niyonsaba, F.; Someya, A.; Hirata, M.; Ogawa, H.; Nagaoka, I. Evaluation of the effects of peptide antibiotics human beta-defensins-1/-2 and LL-37 on histamine release and prostaglandin $\mathrm{D}(2)$ production from mast cells. Eur. J. Immunol. 2001, 31, 1066-1075. [CrossRef]

24. Capone, K.A.; Dowd, S.E.; Stamatas, G.N.; Nikolovski, J. Diversity of the human skin microbiome early in life. J. Investig. Dermatol. 2011, 131, 2026-2032. [CrossRef] [PubMed]

25. Otto, M. Staphylococcus epidermidis-The 'accidental' pathogen. Nat. Rev. Microbiol. 2009, 7, 555-567. [CrossRef] [PubMed]

26. Mah, T.F.; O’Toole, G.A. Mechanisms of biofilm resistance to antimicrobial agents. Trends Microbiol. 2001, 9, 34-39. [CrossRef]

27. Iwase, T.; Uehara, Y.; Shinji, H.; Tajima, A.; Seo, H.; Takada, K.; Agata, T.; Mizunoe, Y. Staphylococcus epidermidis Esp inhibits Staphylococcus aureus biofilm formation and nasal colonization. Nature 2010, 465, 346-349. [CrossRef]

28. Shu, M.; Wang, Y.; Yu, J.; Kuo, S.; Coda, A.; Jiang, Y.; Gallo, R.L.; Huang, C.M. Fermentation of Propionibacterium acnes, a commensal bacterium in the human skin microbiome, as skin probiotics against methicillin-resistant Staphylococcus aureus. PLoS ONE 2013, 8, e55380. [CrossRef] [PubMed]

29. Grice, E.A.; Segre, J.A. The skin microbiome. Nat. Rev. Microbiol. 2011, 9, 244-253. [CrossRef]

30. Korting, H.C.; Hubner, K.; Greiner, K.; Hamm, G.; Braun-Falco, O. Differences in the skin surface pH and bacterial microflora due to the long-term application of synthetic detergent preparations of $\mathrm{pH} 5.5$ and pH 7.0. Results of a crossover trial in healthy volunteers. Acta Derm. Venereol. 1990, 70, 429-431. [PubMed]

31. Ali, S.M.; Yosipovitch, G. Skin pH: From basic science to basic skin care. Acta Derm. Venereol. 2013, 93, $261-267$. [CrossRef] [PubMed]

32. Van Smeden, J.; Bouwstra, J.A. Stratum corneum lipids: Their role for the skin barrier function in healthy subjects and atopic dermatitis patients. Curr. Probl. Dermatol. 2016, 49, 8-26. [CrossRef] [PubMed]

33. Baker, B.S. The role of microorganisms in atopic dermatitis. Clin. Exp. Immunol. 2006, 144, 1-9. [CrossRef]

34. Ohnishi, Y.; Okino, N.; Ito, M.; Imayama, S. Ceramidase activity in bacterial skin flora as a possible cause of ceramide deficiency in atopic dermatitis. Clin. Diagn. Lab. Immunol. 1999, 6, 101-104. [CrossRef] [PubMed]

35. Kim, J.E.; Kim, H.S. Microbiome of the skin and gut in atopic dermatitis (AD): Understanding the pathophysiology and finding novel management strategies. J. Clin. Med. 2019, 8, 444. [CrossRef] [PubMed] 
36. Swe, P.M.; Zakrzewski, M.; Kelly, A.; Krause, L.; Fischer, K. Scabies mites alter the skin microbiome and promote growth of opportunistic pathogens in a porcine model. PLoS Negl. Trop. Dis. 2014, 8, e2897. [CrossRef]

37. Xu, J.; Saunders, C.W.; Hu, P.; Grant, R.A.; Boekhout, T.; Kuramae, E.E.; Kronstad, J.W.; Deangelis, Y.M.; Reeder, N.L.; Johnstone, K.R.; et al. Dandruff-associated Malassezia genomes reveal convergent and divergent virulence traits shared with plant and human fungal pathogens. Proc. Natl. Acad. Sci. USA 2007, 104, 18730-18735. [CrossRef]

38. Mack, M.R.; Kim, B.S. The itch-scratch cycle: A neuroimmune perspective. Trends Immunol. 2018, 39, 980-991. [CrossRef]

39. Potenzieri, C.; Undem, B.J. Basic mechanisms of itch. Clin. Exp. Allergy 2012, 42, 8-19. [CrossRef]

40. Borgono, C.A.; Michael, I.P.; Komatsu, N.; Jayakumar, A.; Kapadia, R.; Clayman, G.L.; Sotiropoulou, G.; Diamandis, E.P. A potential role for multiple tissue kallikrein serine proteases in epidermal desquamation. J. Biol. Chem. 2007, 282, 3640-3652. [CrossRef]

41. Yosipovitch, G.; Misery, L.; Proksch, E.; Metz, M.; Stander, S.; Schmelz, M. Skin barrier damage and itch: Review of mechanisms, topical management and future directions. Acta Derm. Venereol. 2019, 99, 1201-1209. [CrossRef]

42. Komatsu, N.; Saijoh, K.; Kuk, C.; Liu, A.C.; Khan, S.; Shirasaki, F.; Takehara, K.; Diamandis, E.P. Human tissue kallikrein expression in the stratum corneum and serum of atopic dermatitis patients. Exp. Dermatol. 2007, 16, 513-519. [CrossRef] [PubMed]

43. Steinhoff, M.; Neisius, U.; Ikoma, A.; Fartasch, M.; Heyer, G.; Skov, P.S.; Luger, T.A.; Schmelz, M. Proteinase-activated receptor-2 mediates itch: A novel pathway for pruritus in human skin. J. Neurosci. 2003, 23, 6176-6180. [CrossRef]

44. Stefansson, K.; Brattsand, M.; Roosterman, D.; Kempkes, C.; Bocheva, G.; Steinhoff, M.; Egelrud, T. Activation of proteinase-activated receptor-2 by human kallikrein-related peptidases. J. Investig. Dermatol. 2008, 128, 18-25. [CrossRef] [PubMed]

45. Sanders, K.M.; Nattkemper, L.A.; Rosen, J.D.; Andersen, H.H.; Hsiang, J.; Romanelli, P.; Bernigaud, C.; Guillot, J.; Chosidow, O.; Yosipovitch, G. Non-histaminergic itch mediators elevated in the skin of a porcine model of scabies and of human scabies patients. J. Investig. Dermatol. 2019, 139, 971-973. [CrossRef] [PubMed]

46. Niyonsaba, F.; Ushio, H.; Hara, M.; Yokoi, H.; Tominaga, M.; Takamori, K.; Kajiwara, N.; Saito, H.; Nagaoka, I.; Ogawa, H.; et al. Antimicrobial peptides human beta-defensins and cathelicidin LL-37 induce the secretion of a pruritogenic cytokine IL-31 by human mast cells. J. Immunol. 2010, 184, 3526-3534. [CrossRef]

47. Cevikbas, F.; Wang, X.; Akiyama, T.; Kempkes, C.; Savinko, T.; Antal, A.; Kukova, G.; Buhl, T.; Ikoma, A.; Buddenkotte, J.; et al. A sensory neuron-expressed IL-31 receptor mediates T helper cell-dependent itch: Involvement of TRPV1 and TRPA1. J. Allergy Clin. Immunol. 2014, 133, 448-460. [CrossRef]

48. Naik, S.; Bouladoux, N.; Wilhelm, C.; Molloy, M.J.; Salcedo, R.; Kastenmuller, W.; Deming, C.; Quinones, M.; Koo, L.; Conlan, S.; et al. Compartmentalized control of skin immunity by resident commensals. Science 2012, 337, 1115-1119. [CrossRef]

49. Chehoud, C.; Rafail, S.; Tyldsley, A.S.; Seykora, J.T.; Lambris, J.D.; Grice, E.A. Complement modulates the cutaneous microbiome and inflammatory milieu. Proc. Natl. Acad. Sci. USA 2013, 110, 15061-15066. [CrossRef]

50. Lai, Y.; Cogen, A.L.; Radek, K.A.; Park, H.J.; Macleod, D.T.; Leichtle, A.; Ryan, A.F.; Di Nardo, A.; Gallo, R.L. Activation of TLR2 by a small molecule produced by Staphylococcus epidermidis increases antimicrobial defense against bacterial skin infections. J. Investig. Dermatol. 2010, 130, 2211-2221. [CrossRef]

51. Stacy, A.; Belkaid, Y. Microbial guardians of skin health. Science 2019, 363, 227-228. [CrossRef] [PubMed]

52. Lai, Y.; Di Nardo, A.; Nakatsuji, T.; Leichtle, A.; Yang, Y.; Cogen, A.L.; Wu, Z.R.; Hooper, L.V.; Schmidt, R.R.; Von Aulock, S.; et al. Commensal bacteria regulate Toll-like receptor 3-dependent inflammation after skin injury. Nat. Med. 2009, 15, 1377-1382. [CrossRef] [PubMed]

53. Menzies, B.E.; Kenoyer, A. Signal transduction and nuclear responses in Staphylococcus aureus-induced expression of human beta-defensin 3 in skin keratinocytes. Infect. Immun. 2006, 74, 6847-6854. [CrossRef] [PubMed] 
54. Hashimoto, M.; Tawaratsumida, K.; Kariya, H.; Aoyama, K.; Tamura, T.; Suda, Y. Lipoprotein is a predominant Toll-like receptor 2 ligand in Staphylococcus aureus cell wall components. Int. Immunol. 2006, 18, 355-362. [CrossRef]

55. Bubeck Wardenburg, J.; Williams, W.A.; Missiakas, D. Host defenses against Staphylococcus aureus infection require recognition of bacterial lipoproteins. Proc. Natl. Acad. Sci. USA 2006, 103, 13831-13836. [CrossRef]

56. Kim, J.; Ochoa, M.T.; Krutzik, S.R.; Takeuchi, O.; Uematsu, S.; Legaspi, A.J.; Brightbill, H.D.; Holland, D.; Cunliffe, W.J.; Akira, S.; et al. Activation of toll-like receptor 2 in acne triggers inflammatory cytokine responses. J. Immunol. 2002, 169, 1535-1541. [CrossRef]

57. Linehan, J.L.; Harrison, O.J.; Han, S.J.; Byrd, A.L.; Vujkovic-Cvijin, I.; Villarino, A.V.; Sen, S.K.; Shaik, J.; Smelkinson, M.; Tamoutounour, S.; et al. Non-classical immunity controls microbiota impact on skin immunity and tissue repair. Cell 2018, 172, 784-796.e18. [CrossRef]

58. Nakamura, Y.; Oscherwitz, J.; Cease, K.B.; Chan, S.M.; Munoz-Planillo, R.; Hasegawa, M.; Villaruz, A.E.; Cheung, G.Y.; McGavin, M.J.; Travers, J.B.; et al. Staphylococcus delta-toxin induces allergic skin disease by activating mast cells. Nature 2013, 503, 397-401. [CrossRef]

59. Williams, M.R.; Nakatsuji, T.; Gallo, R.L. Staphylococcus aureus: Master manipulator of the skin. Cell Host Microbe 2017, 22, 579-581. [CrossRef]

60. Tebruegge, M.; Kuruvilla, M.; Margarson, I. Does the use of calamine or antihistamine provide symptomatic relief from pruritus in children with varicella zoster infection? Arch. Dis. Child. 2006, 91, 1035-1036. [CrossRef]

61. McKenzie, R.C.; Sauder, D.N. Keratinocyte cytokines and growth factors. Functions in skin immunity and homeostasis. Dermatol. Clin. 1990, 8, 649-661. [CrossRef]

62. Kollisch, G.; Kalali, B.N.; Voelcker, V.; Wallich, R.; Behrendt, H.; Ring, J.; Bauer, S.; Jakob, T.; Mempel, M.; Ollert, M. Various members of the Toll-like receptor family contribute to the innate immune response of human epidermal keratinocytes. Immunology 2005, 114, 531-541. [CrossRef] [PubMed]

63. Lebre, M.C.; Van der Aar, A.M.; Van Baarsen, L.; Van Capel, T.M.; Schuitemaker, J.H.; Kapsenberg, M.L.; De Jong, E.C. Human keratinocytes express functional Toll-like receptor 3, 4, 5, and 9. J. Investig. Dermatol. 2007, 127, 331-341. [CrossRef] [PubMed]

64. Olaru, F; Jensen, L.E. Chemokine expression by human keratinocyte cell lines after activation of Toll-like receptors. Exp. Dermatol. 2010, 19, e314-e316. [CrossRef] [PubMed]

65. Dainichi, T.; Kitoh, A.; Otsuka, A.; Nakajima, S.; Nomura, T.; Kaplan, D.H.; Kabashima, K. The epithelial immune microenvironment (EIME) in atopic dermatitis and psoriasis. Nat. Immunol. 2018, 19, 1286-1298. [CrossRef]

66. Hofmann, A.M.; Abraham, S.N. New roles for mast cells in modulating allergic reactions and immunity against pathogens. Curr. Opin. Immunol. 2009, 21, 679-686. [CrossRef] [PubMed]

67. Igawa, S.; Di Nardo, A. Skin microbiome and mast cells. Transl. Res. 2017, 184, 68-76. [CrossRef]

68. Leon, A.; Rosen, J.D.; Hashimoto, T.; Fostini, A.C.; Paus, R.; Yosipovitch, G. Itching for an answer: A review of potential mechanisms of scalp itch in psoriasis. Exp. Dermatol. 2019, 28, 1397-1404. [CrossRef] [PubMed]

69. Trier, A.M.; Mack, M.R.; Kim, B.S. The neuroimmune axis in skin sensation, inflammation, and immunity. J. Immunol. 2019, 202, 2829-2835. [CrossRef] [PubMed]

70. Walsh, C.M.; Hill, R.Z.; Schwendinger-Schreck, J.; Deguine, J.; Brock, E.C.; Kucirek, N.; Rifi, Z.; Wei, J.; Gronert, K.; Brem, R.B.; et al. Neutrophils promote CXCR3-dependent itch in the development of atopic dermatitis. Elife 2019, 8. [CrossRef] [PubMed]

71. Hashimoto, T.; Rosen, J.D.; Sanders, K.M.; Yosipovitch, G. Possible role of neutrophils in itch. Itch 2018, 3, e17. [CrossRef]

72. Luo, J.; Feng, J.; Liu, S.; Walters, E.T.; Hu, H. Molecular and cellular mechanisms that initiate pain and itch. Cell. Mol. Life Sci. 2015, 72, 3201-3223. [CrossRef]

73. Hashimoto, T.; Satoh, T.; Yokozeki, H. Pruritus in ordinary scabies: IL-31 from macrophages induced by overexpression of thymic stromal lymphopoietin and periostin. Allergy 2019, 74, 1727-1737. [CrossRef] [PubMed]

74. Hashimoto, T.; Kursewicz, C.D.; Fayne, R.A.; Nanda, S.; Shah, S.M.; Nattkemper, L.; Yokozeki, H.; Yosipovitch, G. Mechanisms of itch in stasis dermatitis: Significant role of IL-31 from macrophages. J. Investig. Dermatol. 2020, 140, 850-859. [CrossRef] [PubMed] 
75. Sonkoly, E.; Muller, A.; Lauerma, A.I.; Pivarcsi, A.; Soto, H.; Kemeny, L.; Alenius, H.; Dieu-Nosjean, M.C.; Meller, S.; Rieker, J.; et al. IL-31: A new link between T cells and pruritus in atopic skin inflammation. J. Allergy Clin. Immunol. 2006, 117, 411-417. [CrossRef]

76. Baral, P.; Mills, K.; Pinho-Ribeiro, F.A.; Chiu, I.M. Pain and itch: Beneficial or harmful to antimicrobial defense? Cell Host Microbe 2016, 19, 755-759. [CrossRef] [PubMed]

77. Liu, T.; Gao, Y.J.; Ji, R.R. Emerging role of Toll-like receptors in the control of pain and itch. Neurosci. Bull. 2012, 28, 131-144. [CrossRef]

78. Liu, T.; Xu, Z.Z.; Park, C.K.; Berta, T.; Ji, R.R. Toll-like receptor 7 mediates pruritus. Nat. Neurosci. 2010, 13, 1460-1462. [CrossRef]

79. Liu, T.; Berta, T.; Xu, Z.Z.; Park, C.K.; Zhang, L.; Lu, N.; Liu, Q.; Liu, Y.; Gao, Y.J.; Liu, Y.C.; et al. TLR3 deficiency impairs spinal cord synaptic transmission, central sensitization, and pruritus in mice. J. Clin. Investig. 2012, 122, 2195-2207. [CrossRef]

80. Diogenes, A.; Ferraz, C.C.; Akopian, A.N.; Henry, M.A.; Hargreaves, K.M. LPS sensitizes TRPV1 via activation of TLR4 in trigeminal sensory neurons. J. Dent. Res. 2011, 90, 759-764. [CrossRef]

81. Calil, I.L.; Zarpelon, A.C.; Guerrero, A.T.; Alves-Filho, J.C.; Ferreira, S.H.; Cunha, F.Q.; Cunha, T.M.; Verri, W.A., Jr. Lipopolysaccharide induces inflammatory hyperalgesia triggering a TLR4/MyD88-dependent cytokine cascade in the mice paw. PLoS ONE 2014, 9, e90013. [CrossRef]

82. Min, H.; Lee, H.; Lim, H.; Jang, Y.H.; Chung, S.J.; Lee, C.J.; Lee, S.J. TLR4 enhances histamine-mediated pruritus by potentiating TRPV1 activity. Mol. Brain 2014, 7, 59. [CrossRef] [PubMed]

83. Meseguer, V.; Alpizar, Y.A.; Luis, E.; Tajada, S.; Denlinger, B.; Fajardo, O.; Manenschijn, J.A.; Fernandez-Pena, C.; Talavera, A.; Kichko, T.; et al. TRPA1 channels mediate acute neurogenic inflammation and pain produced by bacterial endotoxins. Nat. Commun. 2014, 5, 3125. [CrossRef] [PubMed]

84. Startek, J.B.; Talavera, K.; Voets, T.; Alpizar, Y.A. Differential interactions of bacterial lipopolysaccharides with lipid membranes: Implications for TRPA1-mediated chemosensation. Sci. Rep. 2018, 8, 12010. [CrossRef]

85. Kashem, S.W.; Riedl, M.S.; Yao, C.; Honda, C.N.; Vulchanova, L.; Kaplan, D.H. Nociceptive sensory fibers drive interleukin-23 production from $\mathrm{CD} 301 \mathrm{~b}^{+}$dermal dendritic cells and drive protective cutaneous immunity. Immunity 2015, 43, 515-526. [CrossRef]

86. Chiu, I.M.; Heesters, B.A.; Ghasemlou, N.; Von Hehn, C.A.; Zhao, F.; Tran, J.; Wainger, B.; Strominger, A.; Muralidharan, S.; Horswill, A.R.; et al. Bacteria activate sensory neurons that modulate pain and inflammation. Nature 2013, 501, 52-57. [CrossRef]

87. Pinho-Ribeiro, F.A.; Baddal, B.; Haarsma, R.; O'Seaghdha, M.; Yang, N.J.; Blake, K.J.; Portley, M.; Verri, W.A.; Dale, J.B.; Wessels, M.R.; et al. Blocking neuronal signaling to immune cells treats streptococcal invasive infection. Cell 2018, 173, 1083-1097.e22. [CrossRef]

88. Hashimoto, T.; Yosipovitch, G. Itching as a systemic disease. J. Allergy Clin. Immunol. 2019, 144, 375-380. [CrossRef]

89. Bajaj, J.S.; Fagan, A.; Sikaroodi, M.; Kakiyama, G.; Takei, H.; Degefu, Y.; Pandak, W.M.; Hylemon, P.B.; Fuchs, M.; John, B.; et al. Alterations in skin microbiomes of patients with cirrhosis. Clin. Gastroenterol. Hepatol. 2019, 17, 2581-2591.e15. [CrossRef]

90. Kremer, A.E.; Martens, J.J.; Kulik, W.; Rueff, F.; Kuiper, E.M.; Van Buuren, H.R.; Van Erpecum, K.J.; Kondrackiene, J.; Prieto, J.; Rust, C.; et al. Lysophosphatidic acid is a potential mediator of cholestatic pruritus. Gastroenterology 2010, 139, 1008-1018.e1. [CrossRef]

91. Beuers, U.; Kremer, A.E.; Bolier, R.; Elferink, R.P. Pruritus in cholestasis: Facts and fiction. Hepatology 2014, 60, 399-407. [CrossRef] [PubMed]

92. Nieto-Posadas, A.; Picazo-Juarez, G.; Llorente, I.; Jara-Oseguera, A.; Morales-Lazaro, S.; Escalante-Alcalde, D.; Islas, L.D.; Rosenbaum, T. Lysophosphatidic acid directly activates TRPV1 through a C-terminal binding site. Nat. Chem. Biol. 2011, 8, 78-85. [CrossRef] [PubMed]

93. Roosterman, D.; Goerge, T.; Schneider, S.W.; Bunnett, N.W.; Steinhoff, M. Neuronal control of skin function: The skin as a neuroimmunoendocrine organ. Physiol. Rev. 2006, 86, 1309-1379. [CrossRef] [PubMed]

94. Pereira, U.; Boulais, N.; Lebonvallet, N.; Lefeuvre, L.; Gougerot, A.; Misery, L. Development of an in vitro coculture of primary sensitive pig neurons and keratinocytes for the study of cutaneous neurogenic inflammation. Exp. Dermatol. 2010, 19, 931-935. [CrossRef] [PubMed] 
95. Mijouin, L.; Hillion, M.; Ramdani, Y.; Jaouen, T.; Duclairoir-Poc, C.; Follet-Gueye, M.L.; Lati, E.; Yvergnaux, F.; Driouich, A.; Lefeuvre, L.; et al. Effects of a skin neuropeptide (substance p) on cutaneous microflora. PLOS ONE 2013, 8, e78773. [CrossRef] [PubMed]

96. N’Diaye, A.; Gannesen, A.; Borrel, V.; Maillot, O.; Enault, J.; Racine, P.J.; Plakunov, V.; Chevalier, S.; Lesouhaitier, O.; Feuilloley, M.G. Substance P and calcitonin gene-related peptide: Key regulators of cutaneous microbiota homeostasis. Front. Endocrinol. (Lausanne) 2017, 8, 15. [CrossRef]

97. N’Diaye, A.; Mijouin, L.; Hillion, M.; Diaz, S.; Konto-Ghiorghi, Y.; Percoco, G.; Chevalier, S.; Lefeuvre, L.; Harmer, N.J.; Lesouhaitier, O.; et al. Effect of substance P in Staphylococcus aureus and Staphylococcus epidermidis virulence: Implication for skin homeostasis. Front. Microbiol. 2016, 7, 506. [CrossRef]

98. Raap, U.; Stander, S.; Metz, M. Pathophysiology of itch and new treatments. Curr. Opin. Allergy Clin. Immunol. 2011, 11, 420-427. [CrossRef]

99. Lenard, J. Mammalian hormones in microbial cells. Trends Biochem. Sci. 1992, 17, 147-150. [CrossRef]

100. Kawashima, K.; Misawa, H.; Moriwaki, Y.; Fujii, Y.X.; Fujii, T.; Horiuchi, Y.; Yamada, T.; Imanaka, T.; Kamekura, M. Ubiquitous expression of acetylcholine and its biological functions in life forms without nervous systems. Life Sci. 2007, 80, 2206-2209. [CrossRef]

101. Stephenson, M.; Rowatt, E. The production of acetylcholine by a strain of Lactobacillus plantarum. J. Gen. Microbiol. 1947, 1, 279-298. [CrossRef] [PubMed]

102. Masson, F.; Talon, R.; Montel, M.C. Histamine and tyramine production by bacteria from meat products. Int. J. Food Microbiol. 1996, 32, 199-207. [CrossRef]

103. Thomas, C.M.; Hong, T.; Van Pijkeren, J.P.; Hemarajata, P.; Trinh, D.V.; Hu, W.; Britton, R.A.; Kalkum, M.; Versalovic, J. Histamine derived from probiotic Lactobacillus reuteri suppresses TNF via modulation of PKA and ERK signaling. PLoS ONE 2012, 7, e31951. [CrossRef]

104. Hurley, R.; Leask, B.G.; Ruthven, C.R.; Sandler, M.; Southgate, J. Investigation of 5-hydroxytryptamine production by Candida albicans in vitro and in vivo. Microbios 1971, 4, 133-143. [PubMed]

105. Asano, Y.; Hiramoto, T.; Nishino, R.; Aiba, Y.; Kimura, T.; Yoshihara, K.; Koga, Y.; Sudo, N. Critical role of gut microbiota in the production of biologically active, free catecholamines in the gut lumen of mice. Am. J. Physiol. Gastrointest. Liver Physiol. 2012, 303, G1288-G1295. [CrossRef] [PubMed]

106. Tsavkelova, E.A.; Botvinko, I.V.; Kudrin, V.S.; Oleskin, A.V. Detection of neurotransmitter amines in microorganisms with the use of high-performance liquid chromatography. Dokl. Biochem. 2000, 372, 115-117. [PubMed]

107. Raasch, W.; Regunathan, S.; Li, G.; Reis, D.J. Agmatine, the bacterial amine, is widely distributed in mammalian tissues. Life Sci. 1995, 56, 2319-2330. [CrossRef]

108. Arena, M.E.; Manca de Nadra, M.C. Biogenic amine production by Lactobacillus. J. Appl. Microbiol. 2001, 90, 158-162. [CrossRef]

109. Leroith, D.; Liotta, A.S.; Roth, J.; Shiloach, J.; Lewis, M.E.; Pert, C.B.; Krieger, D.T. Corticotropin and beta-endorphin-like materials are native to unicellular organisms. Proc. Natl. Acad. Sci. USA 1982, 79, 2086-2090. [CrossRef]

110. LeRoith, D.; Pickens, W.; Vinik, A.I.; Shiloach, J. Bacillus subtilis contains multiple forms of somatostatin-like material. Biochem. Biophys. Res. Commun. 1985, 127, 713-719. [CrossRef]

111. Schar, G.; Stover, E.P.; Clemons, K.V.; Feldman, D.; Stevens, D.A. Progesterone binding and inhibition of growth in Trichophyton mentagrophytes. Infect. Immun. 1986, 52, 763-767. [CrossRef] [PubMed]

112. Cryan, J.F.; Dinan, T.G. Mind-altering microorganisms: The impact of the gut microbiota on brain and behaviour. Nat. Rev. Neurosci. 2012, 13, 701-712. [CrossRef]

113. SM, O.M.; Dinan, T.G.; Cryan, J.F. The gut microbiota as a key regulator of visceral pain. Pain 2017, 158 (Suppl. 1), S19-S28. [CrossRef]

114. Holzer, P.; Farzi, A. Neuropeptides and the microbiota-gut-brain axis. Adv. Exp. Med. Biol. 2014, 817, $195-219$. [CrossRef] [PubMed]

115. Yosipovitch, G.; Ansari, N.; Goon, A.; Chan, Y.H.; Goh, C.L. Clinical characteristics of pruritus in chronic idiopathic urticaria. Br. J. Dermatol. 2002, 147, 32-36. [CrossRef] [PubMed]

116. Yosipovitch, G.; Goon, A.; Wee, J.; Chan, Y.H.; Goh, C.L. The prevalence and clinical characteristics of pruritus among patients with extensive psoriasis. Br. J. Dermatol. 2000, 143, 969-973. [CrossRef] [PubMed] 
117. Yosipovitch, G.; Goon, A.T.; Wee, J.; Chan, Y.H.; Zucker, I.; Goh, C.L. Itch characteristics in Chinese patients with atopic dermatitis using a new questionnaire for the assessment of pruritus. Int. J. Dermatol. 2002, 41, 212-216. [CrossRef]

118. Golpanian, R.S.; Kim, H.S.; Yosipovitch, G. Effects of stress on itch. Clin. Ther. 2020. [CrossRef]

119. Yosipovitch, G.; Mochizuki, H. Neuroimaging of itch as a tool of assessment of chronic itch and its management. Handb. Exp. Pharmacol. 2015, 226, 57-70. [CrossRef]

120. Galley, J.D.; Nelson, M.C.; Yu, Z.; Dowd, S.E.; Walter, J.; Kumar, P.S.; Lyte, M.; Bailey, M.T. Exposure to a social stressor disrupts the community structure of the colonic mucosa-associated microbiota. BMC Microbiol. 2014, 14, 189. [CrossRef]

121. Bailey, M.T. Influence of stressor-induced nervous system activation on the intestinal microbiota and the importance for immunomodulation. Adv. Exp. Med. Biol. 2014, 817, 255-276. [CrossRef] [PubMed]

122. Slominski, A. A nervous breakdown in the skin: Stress and the epidermal barrier. J. Clin. Investig. 2007, 117, 3166-3169. [CrossRef]

123. Aberg, K.M.; Radek, K.A.; Choi, E.H.; Kim, D.K.; Demerjian, M.; Hupe, M.; Kerbleski, J.; Gallo, R.L.; Ganz, T.; Mauro, T.; et al. Psychological stress downregulates epidermal antimicrobial peptide expression and increases severity of cutaneous infections in mice. J. Clin. Investig. 2007, 117, 3339-3349. [CrossRef] [PubMed]

124. Radek, K.A. Antimicrobial anxiety: The impact of stress on antimicrobial immunity. J. Leukoc. Biol. 2010, 88, 263-277. [CrossRef] [PubMed]

125. Kim, H.S.; Yosipovitch, G. An aberrant parasympathetic response: A new perspective linking chronic stress and itch. Exp. Dermatol. 2013, 22, 239-244. [CrossRef] [PubMed]

126. Tran, B.W.; Papoiu, A.D.; Russoniello, C.V.; Wang, H.; Patel, T.S.; Chan, Y.H.; Yosipovitch, G. Effect of itch, scratching and mental stress on autonomic nervous system function in atopic dermatitis. Acta Derm. Venereol. 2010, 90, 354-361. [CrossRef]

127. Curtis, B.J.; Radek, K.A. Cholinergic regulation of keratinocyte innate immunity and permeability barrier integrity: New perspectives in epidermal immunity and disease. J. Investig. Dermatol. 2012, 132, $28-42$. [CrossRef]

128. Radek, K.A.; Elias, P.M.; Taupenot, L.; Mahata, S.K.; O'Connor, D.T.; Gallo, R.L. Neuroendocrine nicotinic receptor activation increases susceptibility to bacterial infections by suppressing antimicrobial peptide production. Cell Host Microbe 2010, 7, 277-289. [CrossRef]

129. Curtis, B.J.; Plichta, J.K.; Blatt, H.; Droho, S.; Griffin, T.M.; Radek, K.A. Nicotinic acetylcholine receptor stimulation impairs epidermal permeability barrier function and recovery and modulates cornified envelope proteins. Life Sci. 2012, 91, 1070-1076. [CrossRef]

130. Lyte, M.; Freestone, P.P.; Neal, C.P.; Olson, B.A.; Haigh, R.D.; Bayston, R.; Williams, P.H. Stimulation of Staphylococcus epidermidis growth and biofilm formation by catecholamine inotropes. Lancet 2003, 361, 130-135. [CrossRef]

131. Freestone, P.P.; Haigh, R.D.; Williams, P.H.; Lyte, M. Stimulation of bacterial growth by heat-stable, norepinephrine-induced autoinducers. FEMS Microbiol. Lett. 1999, 172, 53-60. [CrossRef] [PubMed]

132. Neal, C.P.; Freestone, P.P.; Maggs, A.F.; Haigh, R.D.; Williams, P.H.; Lyte, M. Catecholamine inotropes as growth factors for Staphylococcus epidermidis and other coagulase-negative staphylococci. FEMS Microbiol. Lett. 2001, 194, 163-169. [CrossRef] [PubMed]

133. Borrel, V.; Thomas, P.; Catovic, C.; Racine, P.J.; Konto-Ghiorghi, Y.; Lefeuvre, L.; Duclairoir-Poc, C.; Zouboulis, C.C.; Feuilloley, M.G.J. Acne and stress: Impact of catecholamines on Cutibacterium acnes. Front. Med. (Lausanne) 2019, 6, 155. [CrossRef] [PubMed]

134. Clarke, S.R.; Mohamed, R.; Bian, L.; Routh, A.F.; Kokai-Kun, J.F.; Mond, J.J.; Tarkowski, A.; Foster, S.J. The Staphylococcus aureus surface protein IsdA mediates resistance to innate defenses of human skin. Cell Host Microbe 2007, 1, 199-212. [CrossRef]

135. Freestone, P.P.; Sandrini, S.M.; Haigh, R.D.; Lyte, M. Microbial endocrinology: How stress influences susceptibility to infection. Trends Microbiol. 2008, 16, 55-64. [CrossRef]

136. Pastar, I.; Nusbaum, A.G.; Gil, J.; Patel, S.B.; Chen, J.; Valdes, J.; Stojadinovic, O.; Plano, L.R.; Tomic-Canic, M.; Davis, S.C. Interactions of methicillin resistant Staphylococcus aureus USA300 and Pseudomonas aeruginosa in polymicrobial wound infection. PLoS ONE 2013, 8, e56846. [CrossRef] 
137. Choi, E.H.; Demerjian, M.; Crumrine, D.; Brown, B.E.; Mauro, T.; Elias, P.M.; Feingold, K.R. Glucocorticoid blockade reverses psychological stress-induced abnormalities in epidermal structure and function. Am. J. Physiol. Regul. Integr. Comp. Physiol. 2006, 291, R1657-R1662. [CrossRef]

138. Sandrini, S.M.; Shergill, R.; Woodward, J.; Muralikuttan, R.; Haigh, R.D.; Lyte, M.; Freestone, P.P. Elucidation of the mechanism by which catecholamine stress hormones liberate iron from the innate immune defense proteins transferrin and lactoferrin. J. Bacteriol. 2010, 192, 587-594. [CrossRef]

139. Shibata, M.; Katsuyama, M.; Onodera, T.; Ehama, R.; Hosoi, J.; Tagami, H. Glucocorticoids enhance Toll-like receptor 2 expression in human keratinocytes stimulated with Propionibacterium acnes or proinflammatory cytokines. J. Investig. Dermatol. 2009, 129, 375-382. [CrossRef]

140. Seth, A.K.; Geringer, M.R.; Nguyen, K.T.; Agnew, S.P.; Dumanian, Z.; Galiano, R.D.; Leung, K.P.; Mustoe, T.A.; Hong, S.J. Bacteriophage therapy for Staphylococcus aureus biofilm-infected wounds: A new approach to chronic wound care. Plast. Reconstr. Surg. 2013, 131, 225-234. [CrossRef]

141. Rojas, I.G.; Padgett, D.A.; Sheridan, J.F.; Marucha, P.T. Stress-induced susceptibility to bacterial infection during cutaneous wound healing. Brain Behav. Immun. 2002, 16, 74-84. [CrossRef]

142. Cogen, A.L.; Nizet, V.; Gallo, R.L. Skin microbiota: A source of disease or defence? Br. J. Dermatol. 2008, 158, 442-455. [CrossRef]

143. Sonnex, C. Influence of ovarian hormones on urogenital infection. Sex. Transm. Infect. 1998, 74, 11-19. [CrossRef] [PubMed]

144. Veinante, P.; Yalcin, I.; Barrot, M. The amygdala between sensation and affect: A role in pain. J. Mol. Psychiatry 2013, 1, 9. [CrossRef] [PubMed]

145. Neugebauer, V.; Li, W. Differential sensitization of amygdala neurons to afferent inputs in a model of arthritic pain. J. Neurophysiol. 2003, 89, 716-727. [CrossRef] [PubMed]

146. Neugebauer, V.; Li, W.; Bird, G.C.; Han, J.S. The amygdala and persistent pain. Neuroscientist 2004, 10, $221-234$. [CrossRef]

147. Sanders, K.M.; Akiyama, T. The vicious cycle of itch and anxiety. Neurosci. Biobehav Rev. 2018, 87, 17-26. [CrossRef]

148. Mu, D.; Deng, J.; Liu, K.F.; Wu, Z.Y.; Shi, Y.F.; Guo, W.M.; Mao, Q.Q.; Liu, X.J.; Li, H.; Sun, Y.G. A central neural circuit for itch sensation. Science 2017, 357, 695-699. [CrossRef]

149. Jeong, K.Y.; Kang, J.H. Investigation of the pruritus-induced functional activity in the rat brain using manganese-enhanced MRI. J. Magn. Reson. Imaging 2015, 42, 709-716. [CrossRef]

150. Davidson, S.; Zhang, X.; Khasabov, S.G.; Simone, D.A.; Giesler, G.J., Jr. Relief of itch by scratching: State-dependent inhibition of primate spinothalamic tract neurons. Nat. Neurosci. 2009, 12, 544-546. [CrossRef]

151. Roozendaal, B.; McEwen, B.S.; Chattarji, S. Stress, memory and the amygdala. Nat. Rev. Neurosci. 2009, 10, 423-433. [CrossRef] [PubMed]

152. Pavlenko, D.; Akiyama, T. Why does stress aggravate itch? A possible role of the amygdala. Exp. Dermatol. 2019, 28, 1439-1441. [CrossRef] [PubMed]

153. Mochizuki, H.; Hernandez, L.E.; Yosipovitch, G. What does brain imaging tell us about itch? Itch 2019, 4, e23. [CrossRef]

154. Cowan, C.S.M.; Hoban, A.E.; Ventura-Silva, A.P.; Dinan, T.G.; Clarke, G.; Cryan, J.F. Gutsy moves: The amygdala as a critical node in microbiota to brain signaling. Bioessays 2018, 40. [CrossRef] [PubMed]

155. Stilling, R.M.; Ryan, F.J.; Hoban, A.E.; Shanahan, F.; Clarke, G.; Claesson, M.J.; Dinan, T.G.; Cryan, J.F. Microbes \& neurodevelopment-Absence of microbiota during early life increases activity-related transcriptional pathways in the amygdala. Brain Behav. Immun. 2015, 50, 209-220. [CrossRef] [PubMed]

156. Hoban, A.E.; Stilling, R.M.; Moloney, G.M.; Moloney, R.D.; Shanahan, F.; Dinan, T.G.; Cryan, J.F.; Clarke, G. Microbial regulation of microRNA expression in the amygdala and prefrontal cortex. Microbiome 2017, 5, 102. [CrossRef]

157. Luczynski, P.; Tramullas, M.; Viola, M.; Shanahan, F.; Clarke, G.; O’Mahony, S.; Dinan, T.G.; Cryan, J.F. Microbiota regulates visceral pain in the mouse. Elife 2017, 6. [CrossRef]

158. Sudo, N.; Chida, Y.; Aiba, Y.; Sonoda, J.; Oyama, N.; Yu, X.N.; Kubo, C.; Koga, Y. Postnatal microbial colonization programs the hypothalamic-pituitary-adrenal system for stress response in mice. J. Physiol. 2004, 558, 263-275. [CrossRef] 
159. Clarke, G.; Grenham, S.; Scully, P.; Fitzgerald, P.; Moloney, R.D.; Shanahan, F.; Dinan, T.G.; Cryan, J.F. The microbiome-gut-brain axis during early life regulates the hippocampal serotonergic system in a sex-dependent manner. Mol. Psychiatry 2013, 18, 666-673. [CrossRef]

160. Onaolapo, O.J.; Onaolapo, A.Y.; Olowe, A.O. The neurobehavioral implications of the brain and microbiota interaction. Front. Biosci. (Landmark Ed.) 2020, 25, 363-397. [CrossRef]

161. O'Neill, C.A.; Monteleone, G.; McLaughlin, J.T.; Paus, R. The gut-skin axis in health and disease: A paradigm with therapeutic implications. Bioessays 2016, 38, 1167-1176. [CrossRef] [PubMed]

162. Salem, I.; Ramser, A.; Isham, N.; Ghannoum, M.A. The gut microbiome as a major regulator of the gut-skin axis. Front. Microbiol. 2018, 9, 1459. [CrossRef] [PubMed]

163. Arck, P.; Handjiski, B.; Hagen, E.; Pincus, M.; Bruenahl, C.; Bienenstock, J.; Paus, R. Is there a 'gut-brain-skin axis'? Exp. Dermatol. 2010, 19, 401-405. [CrossRef]

164. Lee, Y.B.; Byun, E.J.; Kim, H.S. Potential role of the microbiome in acne: A comprehensive review. J. Clin. Med. 2019, 8, 987. [CrossRef]

165. Sanders, K.M.; Nattkemper, L.A.; Yosipovitch, G. The gut-itch connection. Exp. Dermatol. 2016, 25, $344-345$. [CrossRef] [PubMed]

166. Castro, J.; Harrington, A.M.; Lieu, T.; Garcia-Caraballo, S.; Maddern, J.; Schober, G.; O’Donnell, T.; Grundy, L.; Lumsden, A.L.; Miller, P.; et al. Activation of pruritogenic TGR5, MrgprA3, and MrgprC11 on colon-innervating afferents induces visceral hypersensitivity. JCI Insight 2019, 4. [CrossRef]

167. Egert, M.; Simmering, R.; Riedel, C.U. The association of the skin microbiota with health, immunity, and disease. Clin. Pharmacol. Ther. 2017, 102, 62-69. [CrossRef]

168. Dreno, B.; Araviiskaia, E.; Berardesca, E.; Gontijo, G.; Sanchez Viera, M.; Xiang, L.F.; Martin, R.; Bieber, T. Microbiome in healthy skin, update for dermatologists. J. Eur. Acad. Dermatol. Venereol. 2016, 30, 2038-2047. [CrossRef]

169. Bastiaanssen, T.F.S.; Cowan, C.S.M.; Claesson, M.J.; Dinan, T.G.; Cryan, J.F. Making sense of ... the microbiome in psychiatry. Int. J. Neuropsychopharmacol. 2019, 22, 37-52. [CrossRef]

170. Davani-Davari, D.; Negahdaripour, M.; Karimzadeh, I.; Seifan, M.; Mohkam, M.; Masoumi, S.J.; Berenjian, A.; Ghasemi, Y. Prebiotics: Definition, types, sources, mechanisms, and clinical applications. Foods 2019, 8, 92. [CrossRef]

(C) 2020 by the authors. Licensee MDPI, Basel, Switzerland. This article is an open access article distributed under the terms and conditions of the Creative Commons Attribution (CC BY) license (http://creativecommons.org/licenses/by/4.0/). 